\title{
Selenium supplementation by addition of sodium selenate with silage additive
}

\author{
Arja Seppälä ${ }^{1}$, Yolanda Madrid Albarran², Harri Miettinen³, Maria Palomo Siguero², Elina Juutinen ${ }^{1,4}$ \\ and Marketta Rinne ${ }^{1}$ \\ ${ }^{1}$ MTT Agrifood Research Finland, Animal Production Research, 31600 Jokioinen, Finland \\ ${ }^{2}$ Department of Analytical Chemistry, Faculty of Chemistry, Complutense University of Madrid, Madrid Ciudad Universitaria s/n \\ 28040 Madrid, Spain \\ ${ }^{3}$ Kemira Oyj, P.O. Box 330, 00101 Helsinki, Finland, current: Nöykkiölaaksontie 27C6, 02330 Espoo, Finland \\ ${ }^{4}$ Current address: Atria Ltd, Finland \\ e-mail: arja.seppala@mtt.fi
}

\begin{abstract}
An ensiling experiment was conducted to assess the possibility for increasing the selenium content in grass silage by using a selenium-enriched silage additive, and to determine possible changes in the form of selenium during ensiling. Prewilted and precision-chopped silage was prepared from the second cut of timothy - meadow fescue sward in southern Finland. The additive treatments $\left(6 \mathrm{~g} \mathrm{~kg}^{-1}\right)$ were: control without additive, water containing 50 $\mathrm{mg}$ sodium selenate $\mathrm{kg}^{-1}$, and formic acid-based additive containing 10, 50 or $500 \mathrm{mg}$ sodium selenate $\mathrm{kg}^{-1}$. The selenium content of the control silage was low $\left(0.069 \mathrm{mg} \mathrm{kg}^{-1} \mathrm{dry}\right.$ matter) whereas the selenium content of the other silages was in line with the dose level of selenium delivered in the additive. The added selenate was detected only as selenate in the silages. Addition of sodium selenate to silage additive provided a controlled way to add selenium to the diet of forage-fed animals.
\end{abstract}

Key words: ensiling, feeding, fermentation, ruminant, selenium

\section{Introduction}

Selenium is a micromineral of fundamental importance to human and animal health, although toxic in excess. It is an essential component of several major metabolic pathways, including thyroid hormone metabolism, antioxidant defence systems and immune function (Brown and Arthur 2001). Low selenium bioavailability in soils in many parts of the world (e.g., parts of Europe and China) is reflected in naturally low selenium content of feedstuffs and in food produced from those areas (Johnson et al. 2010). Selenium-deficiency symptoms have been detected in animals (e.g. white muscle disease) and humans (Keshan disease, endemic cardiomyopathy, heart disease) in areas low in selenium bioavailability (Johnson et al. 2010). The European population has generally low selenium status (Johnson et al. 2010). Potential benefits in terms of improved immune response and reduced cancer incidence and thyroid autoimmune disease risk have been detected and related to increased selenium intake by humans (Rayman 2008). This has encouraged the bringing to market of selenium-enriched food products and selenium supplements in order to alleviate the deficiency (Rayman 2008). Supplement products, however, are not a straightforward solution due to the risks associated with potential selenium overdose from multiple sources (Rayman 2008). Thus, safe means for adding selenium to basic foodstuffs are still needed to ensure the health of both humans and domestic animals.

Although the most severe symptoms of selenium deficiency in cattle (white muscle disease) are quite rare nowadays (Eurola et al. 2011), the less-precise symptoms such as muscular weakness of the newborn, reduced weight gain, diarrhea or decreased fertility (Koller and Exon 1986) may be linked to selenium deficiency. The low selenium content of cows' milk (less than $0.15 \mathrm{mg} \mathrm{kg}^{-1}$ dry matter (DM)) produced on organic farms compared to non-organic milk (average $0.23 \mathrm{mg} \mathrm{kg}^{-1} \mathrm{DM}$ ) reflects the low level of selenium in diets on those farms (Eurola et al. 2011). Keeping in mind the high costs of each case of clinical mastitis (270-670 € per case for dairy cows; Heikkilä et al. 2010), the benefits to udder health from ensuring a sufficient selenium supply (Smith et al. 1985, ref. Smith et al. 1997, Jukola et al. 1996, Giadinis et al. 2011) should be taken into account when planning mineral supplementation of dairy cows as well as lactating ewes. 
In Finland selenium has been added to compound fertilizers since 1984. As a consequence, on average a ten-fold increase in the selenium content of feedstuffs, including silage, has been detected together with decreased incidence of white muscle disease in cattle (from 2846 cases in 1994 to 140 cases in 2009; Eurola et al. 2011). The content of selenium in agricultural soils in Finland has, however, not changed significantly during the three decades (Eurola et al. 2011). In addition, only $4 \%$ of the total selenium in the soil is available to plants (Eurola et al. 2011). Thus, the problem of low selenium-bioavailability persists in the soil and efforts should be made to prevent possible harmful consequences.

Although selenium-enriched fertilizers exist they are not always used, as the additional price of the fertilizer is not directly compensated in terms of increased plant production. Furthermore, in organic farming, the use of compound fertilizers is not allowed. The selenium content of organic silages, or silages produced without compound fertilizers, was only one-tenth that found in conventionally produced silages from grassland fertilized with selenium: 0.02 vs. $0.2 \mathrm{mg} \mathrm{Se} \mathrm{kg}^{-1} \mathrm{DM}$ (Eurola et al. 2011). The selenium content of such silages is not sufficient to fulfil the selenium requirement of cattle $\left(0.1 \mathrm{mg} \mathrm{Se} \mathrm{kg}^{-1} \mathrm{DM}\right.$ according to MTT (2014) or $0.3 \mathrm{mg} \mathrm{Se} \mathrm{kg}^{-1} \mathrm{DM}$ for dairy cattle according to NRC (2001)). Organically produced cereal grains are also low in selenium, so additional selenium sources are needed to ensure sufficient selenium supply to livestock and humans.

Maintenance feeding of ruminants and horses is typically based on forage, possibly supplemented with some minerals. The dosage of mineral feeds may be challenging if silage is fed ad libitum and minerals are offered separately without individual control. Supplementation of individual animals may also not be a practical solution, and therefore forage with sufficient selenium content would be needed. Silage additives are evenly sprayed into the grass material prior to ensiling, and adding selenium to the silage additive might be a practical solution to ensure that the required dose of selenium is applied safely and evenly into the silage.

Selenium compounds authorized in the EU for use as feed additives are sodium selenite, sodium selenate and organic forms of selenium (including selenomethionine) produced by particular strains of Saccharomyces cerevisiae (EFSA 2008). Organic selenium sources are more effective than inorganic selenium salts in raising tissue selenium levels (Weiss and Hogan 2005, EFSA 2008, Ceballos et al. 2009). However, the direct addition of forms of organic selenium to acid-based silage additive is restricted due to possible risk of coagulation in acidic solutions. Laser (2005) reported that during lactic acid fermentation, the added selenate was apparently transformed to compounds of high molecular weight, probably of organic origin. An ensiling experiment was conducted to explore the effect of a sodium selenate-containing silage additive on the selenium content of silage and on the content of different forms of selenium after the ensiling.

\section{Materials and methods}

The study was performed at MTT Agrifood Research Finland in Jokioinen in 2011. A timothy (Phleum pratense) meadow fescue (Festuca pratensis) sward growing on heavy clay soil was fertilized using compound fertilizers without added selenate during summer 2011. The amounts of fertilizers were $250 \mathrm{~kg} \mathrm{ha}^{-1}(22-7, \mathrm{~N}-\mathrm{P})$ in the beginning of growing season and $350 \mathrm{~kg} \mathrm{ha}^{-1}(26-2-4-5, \mathrm{~N}-\mathrm{P}-\mathrm{K}-\mathrm{S})$ after the first cut of grass. The second cut was harvested on 2 August 2011 and prewilted for three hours before harvesting with a precision chopper.

Five batches (each of $25 \mathrm{~kg}$ ) of grass material were weighed and each batch was given the additive treatment according to the design of the experiment (Table 1). The composition of the acid-based additive (AIV Ässä, Kemira Ltd, Helsinki, Finland) used was: $590 \mathrm{~g}$ formic acid, $200 \mathrm{~g}$ propionic acid, $45 \mathrm{~g}$ ammonium formate, $25 \mathrm{~g}$ benzoic acid/sorbate and $140 \mathrm{~g}$ water per $\mathrm{kg}$. The highest level of selenium supplementation was used to check if very high level of inclusion would behave differently than the lower levels. Each batch of grass was mixed manually during and after applying the additive. Three replicate silos (cylinder shape, 12 I volume, $7 \mathrm{~kg}$ grass per silo) were filled from each grass batch. Silos were sealed immediately after filling. The silos were opened and sampled after a 107-day ensiling period. The silos were used as replicates in the statistical analysis as often done in pilot scale ensiling experiments (e.g. Saarisalo et al. 2007, Knicky and Spörndly 2011). The focus was in the changes during fermentation while the dosage level of additive was regarded as background information. 
Table 1. Experimental treatments with additive dose level of $6 \mathrm{~g} \mathrm{~kg}^{-1}$.

\begin{tabular}{lccc}
\hline Abbreviation & Additive treatment & \multicolumn{2}{c}{$\begin{array}{c}\text { Added selenium to grass, mg kg-1 } \\
\text { Selenium }\end{array}$} \\
\hline Control & Water & Sodium selenate & - \\
W50 & Water with $50 \mathrm{mg} \mathrm{kg}^{-1}$ sodium selenate & 0.30 & 0.125 \\
A10 & Acid-based additive with $10 \mathrm{mg} \mathrm{kg}^{-1}$ sodium selenate & 0.06 & 0.025 \\
A50 & Acid-based additive with $50 \mathrm{mg} \mathrm{kg}^{-1}$ sodium selenate & 0.30 & 0.125 \\
A500 & Acid-based additive with $500 \mathrm{mg} \mathrm{kg}^{-1}$ sodium selenate & 3.00 \\
\hline
\end{tabular}

Chemical analyses related to chemical composition of the grass prior to ensiling and to silage fermentation quality were carried out at the MTT Laboratory in Jokioinen. The laboratory has a quality system which follows the SFSEN ISO/IEC 17025:2005 standards and it is accredited by FINAS (the Finnish Accreditation Service) with number T024. The DM concentration was determined by drying at $105^{\circ} \mathrm{C}$ for $16 \mathrm{~h}$ and samples for chemical analyses were dried at $60{ }^{\circ} \mathrm{C}$ until dry. Ash content was determined using a standard method of AOAC (1990; method 942.05). Nitrogen $(N)$ content was determined by the Dumas method (AOAC method 968.06) using a Leco FP 428 nitrogen analyzer. Crude protein content was calculated as $6.25 \times \mathrm{N}$ content. Concentration of neutral detergent insoluble fibre (NDF) was determined according to Van Soest et al. (1991) using sodium-sulphite, without amylase and presented ash free. In vitro pepsin cellulase solubility of the grass was determined according to Huhtanen et al. (2006).

Silages were analysed for volatile fatty acids (VFA) according to Huhtanen et al. (1998), lactic acid according to Haacker et al. (1983), water soluble carbohydrates (WSC) according to Somogyi (1945) and ammonia N according to McCullough (1967). Oven DM concentration of silage was corrected for the loss of volatiles according to Huida et al. (1986).

The analysis of the total selenium content and identification of selenium forms were conducted in the Department of Analytical Chemistry in Faculty of Chemical Sciences, Ciudad University in Madrid, Spain. The determination of the total selenium content was carried out by inductively coupled plasma mass spectrometry (ICP-MS) (HP 7700 Agilent Technologies, Santa Clara, California, United States) after a microwave acid digestion. Each dry sample $(50 \mathrm{mg})$ was weighed and $1 \mathrm{~mL}$ of nitric acid $\left(650 \mathrm{~g} \mathrm{~kg}^{-1}\right)$ and $0.3 \mathrm{ml}$ of hydrogen peroxide $\left(350 \mathrm{~g} \mathrm{~kg}^{-1}\right)$ were added. The samples were subjected to acid digestion in a microwave oven $\left(0-130^{\circ} \mathrm{C}\right.$ for 15 min followed by 130 ${ }^{\circ} \mathrm{C}$ for $10 \mathrm{~min}$ ). After digestion, the resulting extracts were diluted with Milli-Q water up to a final volume of $12 \mathrm{ml}$. Samples were analysed in triplicate.

Identification of selenium species of silage samples was carried out by high-performance liquid chromatography coupled to inductively coupled plasma mass spectrometry (HPLC-ICP-MS) (HP 7700 Agilent, Santa Clara, California, United States) after an enzymatic hydrolysis with protease. The recovery of selenium present in the samples after the enzymatic hydrolysis was more than $95 \%$. The extraction of selenium species from $50 \mathrm{mg}$ of dry sample was performed by 2 min sonication after the addition of $3 \mathrm{ml}$ of buffer Tris- $\mathrm{HCl}(30 \mathrm{mM}, \mathrm{pH} 7.5)$ and $0.020 \mathrm{mg}$ of Protease type XIV isolated from Streptomyces griseus, $\geq 3.5$ units $1 \mathrm{mg}^{-1}$ solid (purchased from Sigma-Aldrich, St. Louis, USA). The extracts were centrifuged at $11000 \mathrm{rpm}$ for $15 \mathrm{~min}$ and then filtered by means of using $0.20 \mu \mathrm{m}$ nylon filters. The supernatants were analysed by anion exchange chromatography coupled to ICP-MS. The concentrations of selenium species were determined by monitoring ${ }^{77} \mathrm{Se},{ }^{78} \mathrm{Se}$, and ${ }^{82} \mathrm{Se}$ isotopes by comparison to known standards solutions. The identification was performed by comparing retention times with those of standard solutions. The standard included selenocysteine $\left(\mathrm{SeCys}_{2}\right)$, seleno-methyl-selenocysteine (SeMetSeCys), selenite Se(IV), selenomethionine (SeMet) and selenate (Se(VI)).

Statistical analyses were performed using SAS GLM-procedure. Treatment effects on fermentation quality and selenium content of the silages were tested by a one-way analysis of variance and differences between treatments (Ismeans) were compared using the Tukey test. 


\section{Results \\ Chemical composition of grass material}

The harvested grass prior to ensiling had a DM content of $283 \mathrm{~g} \mathrm{~kg}^{-1}$. In DM, the contents of ash, crude protein, WSC and NDF were 113, 175, 147 and $536 \mathrm{~g} \mathrm{~kg}^{-1}$, respectively. The digestible organic matter content before ensiling was $667 \mathrm{~g} \mathrm{~kg}^{-1} \mathrm{DM}$.

\section{Fermentation quality of the silages}

The formic acid-based silage additive restricted fermentation and resulted in higher final $\mathrm{pH}$ compared to the Control and WO treatments, as acid-based additive silages had more WSC, less fermentation products and less ammonium $\mathrm{N}$ than the silages without the acid-based additive $(p<0.001$; Table 2$)$. The treatment $A 500$ restricted fermentation more than the lower levels of selenium addition ( 110 and A50) as indicated by the highest WSC content and lowest lactic acid content. A500 silages contained more propionic acid than the other treated silages.

Table 2. Fermentation quality of the silages (units $\mathrm{g} \mathrm{kg}^{-1}$ dry matter (DM) unless otherwise stated). W50 = Water with 50 mg $\mathrm{kg}^{-1}$ sodium selenate, $\mathrm{A} 10$ = Acid-based additive with $10 \mathrm{mg} \mathrm{kg}^{-1}$ sodium selenate, A50 = Acid-based additive with 50 mg kg-1 sodium selenate, $\mathrm{A} 500$ = Acid-based additivewith $500 \mathrm{mg} \mathrm{kg}^{-1}$ sodium selenate. Treatment means within the same row but without the same superscript are statistically different ( $p<0.05$, Tukey test).

\begin{tabular}{|c|c|c|c|c|c|c|c|}
\hline & Control & W50 & A10 & A50 & A500 & SEM $^{1}$ & $\begin{array}{c}\text { Treatment } \\
\text { effect }\end{array}$ \\
\hline DM, $\mathrm{g} \mathrm{kg}^{-1}$ & 288 & 288 & 279 & 289 & 288 & 0.8 & ns \\
\hline $\mathrm{pH}$ & $4.20^{\mathrm{b}}$ & $4.20^{\mathrm{b}}$ & $4.30^{\mathrm{a}}$ & $4.27^{\mathrm{ab}}$ & $4.32^{a}$ & 0.018 & $<0.001$ \\
\hline Lactic acid & $99.7^{a}$ & $97.8^{a}$ & $61.2^{\mathrm{b}}$ & $66.5^{b}$ & $41.2^{\mathrm{c}}$ & 2.29 & $<0.001$ \\
\hline Acetic acid & $21.18^{\mathrm{a}}$ & $21.07^{a}$ & $9.65^{b}$ & $9.51^{b}$ & $9.29^{b}$ & 0.458 & $<0.001$ \\
\hline Propionic acid & $0.21^{c}$ & $0.15^{c}$ & $2.94^{b}$ & $2.89^{b}$ & $4.14^{a}$ & 0.211 & $<0.001$ \\
\hline VFA4-VFA $6^{2}$ & 0.28 & 0.33 & 0.16 & 0.13 & 0.4 & 0.087 & ns \\
\hline WSC $^{3}$ & $14.0^{c}$ & $14.1^{\mathrm{c}}$ & $62.4^{b}$ & $60.5^{b}$ & $80.1^{a}$ & 2.38 & $<0.001$ \\
\hline Ammonium, $\mathrm{N} \mathrm{g} \mathrm{kg}^{-1} \mathrm{~N}^{4}$ & $65.2^{\mathrm{a}}$ & $69.0^{a}$ & $20.8^{b}$ & $16.4^{b}$ & $28.0^{\mathrm{b}}$ & 3.64 & $<0.001$ \\
\hline
\end{tabular}

${ }^{1} \mathrm{SEM}=$ Standard error of the mean

${ }^{2}$ VFA4-VFA6 = the sum of buturyc, isobutyric, valeric, isovaleric and caproic acids ${ }^{3}$ Water soluble carbohydrates

${ }^{4}$ Not corrected for the ammonium included in the additive.

\section{Selenium content and selenium forms in the silages}

Selenium dosed within the additive was evenly sprayed into the silage with the acid-based additive as indicated by the total selenium content of the silages being close to the theoretical concentration (Table 3). The largest deviation ( $45 \%$ ) was observed in the W50 treatment. Nearly all ( $95 \%$ ) of the total selenium was detected as sodium selenate and no other selenium forms were detected. 
Table 3. Expected and analysed selenium content in the silages. Selenium content expressed as mg Se kg-1 dry matter. $\mathrm{W} 50=$ Water with $50 \mathrm{mg} \mathrm{kg}^{-1}$ sodium selenate, $\mathrm{A} 10=$ Acid-based additive with $10 \mathrm{mg} \mathrm{kg}^{-1}$ sodium selenate, A50 = Acid-based additive with $50 \mathrm{mg} \mathrm{kg}^{-1}$ sodium selenate, A500 = Acid-based additive with $500 \mathrm{mg} \mathrm{kg}^{-1}$ sodium selenate. Treatment means within same row without same superscript are statistically different $(p<0.05$, Tukey test).

\begin{tabular}{|c|c|c|c|c|c|c|c|}
\hline & Control & W50 & A10 & A50 & A500 & SEM $^{1}$ & $\begin{array}{c}\text { Treatment } \\
\text { effect }\end{array}$ \\
\hline Expected selenium content ${ }^{2}$ & - & 0.507 & 0.157 & 0.507 & 4.453 & & \\
\hline Analysed total selenium ${ }^{3}$ & $0.069^{a}$ & $0.920^{b}$ & $0.159^{a}$ & $0.496^{\mathrm{ab}}$ & $4.199^{c}$ & 0.125 & $<0.001$ \\
\hline Selenium detected as selenate ${ }^{4}$ & $0.000^{a}$ & $0.667^{a}$ & $0.156^{a}$ & $0.486^{a}$ & $4.457^{b}$ & 0.193 & $<0.001$ \\
\hline
\end{tabular}

${ }^{1} \mathrm{SEM}=$ Standard error of the mean

${ }^{2}$ Calculated as the sum of the selenium content of the Control silage and the amount of selenium theoretically provided with the additive treatment.

${ }^{3}$ Determined by inductively coupled plasma mass spectrometry (ICP-MS)

${ }^{4}$ Determined by high-performance liquid chromatography coupled to inductively coupled plasma mass spectrometry (HPLC-ICP-MS)

\section{Discussion}

\section{Fermentation quality of the silages}

All the silages in this experiment had very good fermentation quality according to the DLG criteria (Kaiser et al. 2006) as the amount of butyric acid was negligible (the sum of butyric, isobutyric, valeric, isovaleric and capronic acids was less than $0.8 \mathrm{~g} \mathrm{~kg}^{-1} \mathrm{DM}$ ) and the amount of acetic acid was low in all silages. However, according to the silage quality grading system used in Finland (Artturi 2014) the Control and W50 silages were not considered of good quality because of their high ammonium content, low sugar content and slightly too high acetic acid concentration. Furthermore, their palatability may have been adversely affected due to the high amount of fermentation products as demonstrated by the relative silage DM intake index (Huhtanen et al. 2007), which was 91.0., $91.3,96.5,96.5$, and 99.5 for the silages Control, W50, A10, A50 and A500, respectively (a higher value indicates a higher relative intake potential; note that values for D-value and NDF concentration from the grass ensiled were used in the calculations).

These results suggest that the highest level of selenium addition would further restrict lactic acid fermentation compared to the other acid treatments, and on the other hand promote the production of propionic acid. This finding has little practical value, as the selenium level in the A500 treatment was higher than the amount that can safely be used for ensiling animal feeds (MMM 43/2005).

Losses during ensiling could have effect on the selenium content of silage. If low DM silages would be ensiled that produce effluent, a significant amount of the selenium added in the additive may be lost with the effluent. In this experiment, the losses during an ensiling were however small (the maximum recorded weight change during ensiling was only $9.4 \mathrm{~g} \mathrm{~kg}^{-1}$ ensiled grass) and this would have only negligible effect on the selenium content of silage.

\section{Selenium level in the additive}

The Control silage had a total selenium content of $0.069 \mathrm{mg} \mathrm{kg}^{-1} \mathrm{DM}$ (Table 3), which is clearly below the selenium

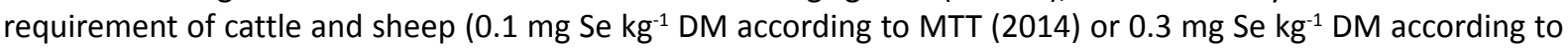
NRC for dairy cattle (2001)). The lowest level of addition of sodium selenate produced silage that had a content of selenium $\left(0.159 \mathrm{mg} \mathrm{kg}^{-1}\right)$ that fulfilled the Finnish selenium requirements. The intermediate level of addition resulted in silage that had a selenium content $65 \%$ above the NRC (2001) recommendation for dairy cattle, but this was still lower than the highest permitted selenium content in feed. The selenium content should not exceed 0.5 $\mathrm{mg} \mathrm{kg}^{-1}$ in a feed ration having $12 \%$ DM content (MMM 43/2005), which is equal to $0.568 \mathrm{mg} \mathrm{kg}^{-1} \mathrm{DM}$. The highest application level resulted in selenium content in silage that was 7.4-times higher than the maximum allowed level. 
The selenium requirement for dairy cattle is higher $\left(0.3 \mathrm{mg} \mathrm{kg}^{-1} \mathrm{DM}, \mathrm{NRC} 2001\right)$ than for beef cattle $\left(0.1 \mathrm{mg} \mathrm{kg}^{-1}\right.$ DM, NRC 2000) to ensure optimal udder health (Jukola et al. 1996). Smith et al. $(1985,1997)$ found over $30 \%$ reduction in the number of cases of clinical mastitis and nearly a $70 \%$ reduction in the number of high somatic-cellcount cows (lactation average somatic cell counts greater than $200000 \mathrm{ml}^{-1}$ ) as a result of supplementation with Se and vitamin E. Flocks of dairy sheep having high incidence rates of clinical mastitis ( $>10 \%$ ) were found to have lower $(p<0.001)$ blood selenium and serum vitamin A concentrations than flocks with low rates of incidence of mastitis $(<3 \%)$, while no relationship between blood vitamin E concentration and mastitis incidence was found (Giadinis et al. 2011). These authors suggested that the selenium status of ewes may possibly be used to indicate animals at risk of developing clinical mastitis.

There are several aspects to be taken into account when optimizing the level of selenium inclusion in the silage additive. The inclusion should be sufficient for the selenium to have positive effects on animal health, but there is a need to ensure the amount is still safe, and takes into account situations where the grass has also received selenium-enriched fertilizers. The increased use of selenium in the diet (either as part of basal feeds or in the form of mineral supplementation) can be expected to increase the selenium content of the animal excreta. However, administering selenium via the silage additive should be similar to situations when selenium is provided to the animals by use of selenium enriched fertilizers and/or in the dietary supplements. In Finland, it seems that low selenium bioavailability in soil is not yet overcame despite three decades of usage of selenium enriched fertilizers (Eurola et al. 2011). Thus accumulative poisonous effect over years seems to be a remote concern.

The optimization of the selenium content in the additive is complicated by the fact that the dosage recommendations of silage additives are typically expressed on fresh-matter basis and the DM content of the grass typically varies from 200 to $400 \mathrm{~g} \mathrm{~kg}^{-1}$. Two possible scenarios are presented in Table 4 . The lower level of inclusion (4.67 mg selenium $\mathrm{kg}^{-1}$ additive, $11 \mathrm{mg} \mathrm{kg}^{-1}$ sodium selenate) is sufficient to prevent selenium deficiency in cattle having silage as their sole feed, despite low inherent selenium content in the grass. The maximum allowed inclusion of selenium (6.61 mg selenium kg-1 additive, $15 \mathrm{mg} \mathrm{kg}^{-1}$ sodium selenate) was calculated by assuming low DM content of the grass and high inherent selenium content. These two cases demonstrate that the selenium content of the silage additive can vary only within a relatively narrow range.

Table 4. Two scenarios to optimize selenium (Se) inclusion level in silage additive.

Grass material

Low selenium, high dry matter (DM) High selenium, low DM

\begin{tabular}{|c|c|c|}
\hline Se, $\mathrm{mg} \mathrm{kg}^{-1} \mathrm{DM}$ grass $^{1}$ & 0.030 & 0.370 \\
\hline $\mathrm{DM}, \mathrm{g} \mathrm{kg}^{-1}$ & 400 & 200 \\
\hline $\begin{array}{l}\text { Required addition of Se to reach minimum recommended } \\
\text { level in grass }{ }^{2}, \mathrm{mg} \mathrm{Se} \mathrm{kg}^{-1} \mathrm{DM} \text { grass }\end{array}$ & 0.07 & 0 \\
\hline Maximum safe Se addition ${ }^{3}, \mathrm{mg} \mathrm{Se} \mathrm{kg}^{-1} \mathrm{DM}$ grass & & 0.198 \\
\hline Additive dosage $\mathrm{e}^{4} \mathrm{~g} \mathrm{~kg}^{-1} \mathrm{DM}$ grass & 15 & 30 \\
\hline $\begin{array}{l}\text { Required addition of } \mathrm{Se} \text { to reach the minimum level of } \\
\text { selenium in grass, } \mathrm{mg} \mathrm{Se} \mathrm{kg}^{-1} \text { additive }\end{array}$ & 4.67 & \\
\hline Maximum safe selenium addition, $\mathrm{mg} \mathrm{Se} \mathrm{kg}^{-1}$ additive & & 6.61 \\
\hline \multicolumn{3}{|c|}{ 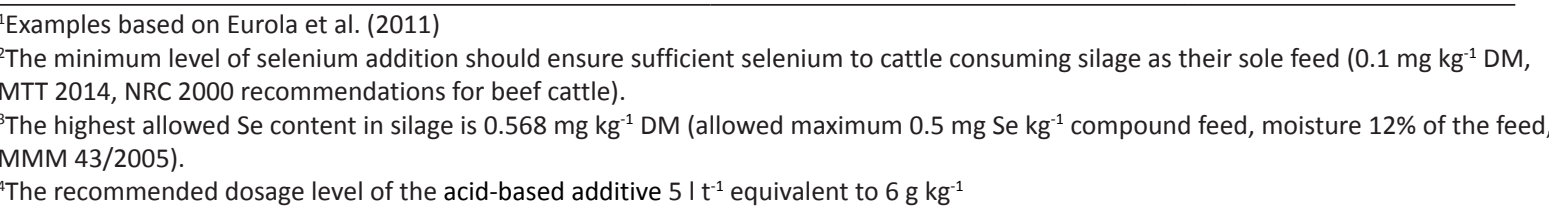 } \\
\hline
\end{tabular}




\section{Selenium chemical forms}

In this experiment, no biotransformation to organic forms of selenium during ensiling was observed, and selenate remained almost unaltered during the ensiling process in contrary to the findings of Laser (2005). Our results are in line with previous studies in which selenium biotransformation was observed only when lactic acid fermentation of milk was carried out in the presence of selenite, not selenate (Alzate et al. 2007). During lactic acid fermentation in the presence of selenite, organic forms selenomethylselenocysteine or selenocysteine were produced (Alzate et al. 2007, 2008, Peñas et al. 2012). According to the safety data sheet (Acros Organics 2009), sodium selenite will release toxic gas in contact with acids, and therefore the addition of sodium selenite into an acid-based additive can be regarded as dangerous.

\section{Conclusions}

Addition of sodium selenate to silage additive provided a controlled way to add selenium to the diet of foragefed animals. Silage additives are applied evenly to the material at ensilage so as to ensure successful ensiling; this would, at the same time, allow the possibility of distributing selenium evenly to animals consuming the silage without additional labour costs. The volume of added selenium is so small that it can be included into the acidbased additive without changing the dosage recommendations. The incremental addition of selenium into the additive could take place in the controlled environment of the factory, thus posing no danger to farmers or consumers. The level of selenium inclusion can be chosen so that selenium-deficiency symptoms are prevented but without the risk of exceeding the highest allowed selenium content of the diet, taking account of grass material that has also received selenium enriched fertilizers.

\section{References}

Acros Organics 2009. Material Safety Data Sheet, Sodium Selenite, Anhydrous, 44-46 \% Se. http://www.chemdb-portal.cn/fisher_msds_pdf/10102-18-8_EN.pdf. Cited 18 December 2013.

Alzate, A., Cañas, B., Pérez-Munguía, S., Hernandez Mendoza, H. C., Pérez-Conde, M. C., Gutiérrez, A.M. \& Cámara, C. 2007. Evaluation of the inorganic selenium biotranformation in selenium enriched yogurt by HPLCeICP-MS. Journal of Agricultural and Food Chemistry 55: 9776-9783.

Alzate, A., Fernandez-Fernandez, A., Pérez-Conde, M. C., Gutiérrez, A. M., \& Cámara, C. 2008. Comparison of biotransformation of inorganic selenium by Lactobacillus and Saccharomyces in lactic fermentation process of yogurt and kefir. Journal of Agricultural and Food Chemistry, 56:18 8728-8736.AOAC 1990. Official Methods of Analysis. Association of Official Analytical Chemists, Inc., Arlington, VA. 1298 p.

Artturi, 2014. ARTTURI ${ }^{\circledR}$ web service. https://portal.mtt.fi/portal/page/portal/Artturi. Cited 24 June 2014.

Brown, K.M. \& Arthur, J.R. 2001. Selenium, selenoproteins and human health: a review. Public Health Nutrition 4(2B): 593-599.

Ceballos, A., Sánchez, J., Stryhn, H., Montgomery, J. B., Barkema, H. W. \& Wichtel J. J. 2009. Meta-analysis of the effect of oral selenium supplementation on milk selenium concentration in cattle. Journal of Dairy Science 92: 324-342.

EFSA 2008. Selected trace and ultratrace elements: Biological role, content in feed and requirements in animal nutrition - Elements for risk assessment. Van Paemel, M., Dierick, N., Janssens, G., Fievez, V. and De Smet, S.. Question No EFSA-Q-2008-04990. http://www.efsa.europa.eu/en/supporting/pub/68e.html.Cited 18 December 2013.

Eurola, M., Alfthan, G., Ekholm, P., Root, T., Suoniitty, T., Venäläinen, E.-R. \& Ylivainio, K. 2011. Seleenityöryhmän raportti 2011. MTT Raportti 35.34 p. (in Finnish).

Giadinis, N.D., Panousis, N., Petridou, E.J., Siarkou, V.I., Lafi, S.Q., Pourliotis, K., Hatzopoulou, E. \& Fthenakis, G.C. 2011. Selenium, vitamin $\mathrm{E}$ and vitamin $\mathrm{A}$ blood concentrations in dairy sheep flocks with increased or low clinical mastitis incidence. Small Ruminant Research 95: 193-196.

Haacker, K., Block, H.J. \& Weissbach, F. 1983. Zur kolorimetrischen Milchsäurebestimmung in Silagen mit p-Hydroxydiphenyl.. Archiv für Tierernährung 33: 505-512. (in German).

Heikkilä, A-M., Nousiainen, J. \& Pyörälä, S. 2010. Kallis utaretulehdus. In: Hopponen, A. (ed.). Maataloustieteen Päivät 2010, Suomen maataloustieteellisen seuran tiedote 26. http://www.smts.fi/jul2010/esite2010/089.pdf. Cited 18 December 2013.

Huhtanen, P.J., Blauwiekel, R. \& Saastamoinen, I. 1998. Effects of intraruminal infusions of propionate and butyrate with two different protein supplements on milk production and blood metabolites in dairy cows receiving grass silage based diet. Journal of the Science of Food and Agriculture 77: 213-222.

Huhtanen, P., Nousiainen, J. \& Rinne, M. 2006. Recent developments in forage evaluation with special reference to practical applications. Agricultural and Food Science 15: 293-323.

Huhtanen, P., Rinne, M. \& Nousiainen, J. 2007. Evaluation of the factors affecting silage intake of dairy cows: a revision of the relative silage dry-matter intake index. Animal 1: 758-770. 
Huida, L., Väätäinen, H. \& Lampila, M. 1986. Comparison of dry matter contents in grass silages as determined by oven drying and gas chromatographic water analysis. Annales Agriculturae Fenniae 25: 215-230.

Johnson, C.C., Fordyce, F.M. \& Rayman, M.P. 2010. Factors controlling the distribution of selenium in the environment and their impact on health and nutrition. Proceedings of the Nutrition Society 69: 119-132.

Jukola, E., Hakkarainen, J., Saloniemi, H. \& Sankari, S. 1996. Blood Selenium, Vitamin E, Vitamin A, and B-Carotene Concentrations and Udder Health, Fertility Treatments, and Fertility. Journal of Dairy Science 79: 838-845.

Kaiser, E., Weiß, K., Nußbaum, H.-J., Kalzendorf, K., Pahlow, G., Schenkel, H., Schwarz, F.J., Spiekers, H., Staudacher, W. \& Thaysen, J. 2006. Grubfutterbewertung. Teil B- DLG-Schlüssel zur Beurteilung derGärqualität von Grünfuttersilagen auf Basis der chemischen Untersuchung. DLG_Information 2/2006. http://www.dlg.org/fileadmin/downloads/fachinfos/futtermittel/grobfutterbewertung_B.pdf. Cited 18 December 2013.

Koller, L.D. \& Exon, J.H. 1986. The two faces of selenium - deficiency and toxicity - are similar in animals and man. Canadian Journal Veterinary Research 50: 297-306.

Knicky, M. \& Spörndly, R. 2011. The ensiling capability of a mixture of sodium benzoate, potassium sorbate, and sodium nitrite. Journal of Dairy Science 94: 824-831.

Laser, H. 2005. Selen-Anreicherung von Saat- und Siliergut als adäquate Methoden der Supplementierung bei Mutterkühen und Fleischrindern in Weidesystemen. Pflanzenbauwissenschaften 2/2005. (in German).

McCullough, H. 1967. The determination of ammonia in whole blood by direct colorimetric method. Clinica Chimica Acta 17: 297-304.

MMM 43/2005. Maa- ja metsätalousministeriön asetus rehun lisäaineista ASETUS nro 43/05 Liite 1. Valmistajakohtaisesti hyväksyttävät sekä jakelu- ja käyttörajoituksien alaiset lisäaineet.

MTT 2014. Feed tables and nutrient requirements. https://portal.mtt.fi/portal/page/portal/Rehutaulukot/feed_tables_english/ nutrient_requirementr/Ruminants/microminerals_cattle. Cited 24 June 2014.

NRC 2000. Nutrient Requirements of Beef Cattle. Seventh Revised Edition: National Research Counsil, Washington D.C.

NRC 2001. Nutrient Requirements of Dairy Cattle. Seventh Revised Edition, National Research Counsil, Washington D.C.

Penas E. Martinez-Villaluenga C., Frias J., Sánchez-Martínez, M.J., Pérez-Corona, M.T., Madrid, Y., Cámara, C. \& Vidal-Valverde, C. 2012. Se improves indole glucosinolate hydrolysis products content, Se-methylselenocysteine content, antioxidant capacity and potential anti-inflammatory properties of sauerkraut. Food chemistry 132: 907-914.

Rayman, M.P. 2008. Food-chain selenium and human health: emphasis on intake. Review Article. British Journal of Nutrition 100: 254-268.

Saarisalo, E., Skyttä, E., Haikara, A., Jalava, T., \& Jaakkola, S. 2007. Screening and selection of lactic acid bacteria strains suitable for ensiling grass. Journal of Applied Microbiology 102: 327-336.

Somogyi, M. 1945. A new reagent for the determination of sugars. Journal of Biological Chemistry 160: 61-68.

Smith, K.L., Hogan, J.S. \& Weiss, W.P. 1997. Dietary vitamin E and selenium affect mastitis and milk quality. Journal Animal Science 75: 1659-1665.

Smith, K.L., Conrad, H.R., Amiet, B.A. \& Todhunter, D.A. 1985. Incidence of environmental mastitis as influenced by dietary vitamin-e and selenium. Kieler Milchwirtschaftliche Forschungsberichte 37:482-486.

Van Soest, P.J., Robertson, J.B. \& Lewis, B.A. 1991. Methods for dietary fibre, neutral detergent fibre and nonstarch polysaccharides in relation to animal nutrition. Journal of Dairy Science 74: 3583-3597.

Weiss, W. P. \& Hogan, J. S.2005. Effect of Selenium Source on Selenium Status, Neutrophil Functionand Response to Intramammary Endotoxin Challenge of Dairy Cows. Journal of Dairy Science 88: 4366-4374. 